\title{
Cretaceous dykes discovered in the Falkland Islands: implications for regional tectonics in the South Atlantic
}

\author{
P. Stone ${ }^{1}$, P C. Richards ${ }^{1}$, G. S. Kimbell ${ }^{2}$, R. P. Esser $^{3}$ and D Reeves ${ }^{4}$ \\ ${ }^{1}$ British Geological Survey, Murchison House, West Mains Rd, Edinburgh, EH9 3LA, \\ UK (e-mail psto@bgs.ac.uk or pcr@bgs.ac.uk ) \\ ${ }^{2}$ British Geological Survey, Keyworth, Nottingham, NG12 5GG, UK \\ ${ }^{3}$ New Mexico Geochronological Research Laboratory, 801 Leroy Place, Socorro, \\ NM 87801, USA \\ ${ }^{4}$ Falkland Gold and Minerals Ltd, Stanley, Falkland Islands
}

\begin{abstract}
New aeromagnetic data resolve the dykes of the Falkland Islands into three swarms. A hitherto unrecognised suite of $\mathrm{N}-\mathrm{S}$ dykes is established as early Cretaceous by an Ar-Ar date of about 121 Ma. Swarms of NE-SW and E-W dykes are both early Jurassic: the former gives an Ar-Ar age of about $178 \mathrm{Ma}$, whilst the latter has been previously dated to about $190 \mathrm{Ma}$. The intrusion of the Cretaceous dykes marks the onset of oceanic crust generation in the South Atlantic and so restricts to mid-Jurassic the microplate rotation envisaged in most models for the Falklands break-out from Gondwana.
\end{abstract}

The Siluro-Devonian to Permian sedimentary rocks of the Falkland Islands (Aldiss \& Edwards 1999 and references therein) are cut by over 400 dolerite dykes, previously grouped into two main but intersecting swarms (Fig. 1A): a NE-SW trending swarm (the "north-south" swarm sl) located mainly in West Falkland; and a broadly WNWESE trending swarm (the "east-west" swarm sl), entirely confined to the south of West Falkland and its outlying islands (Taylor \& Shaw 1989; Musset \& Taylor 1994; Mitchell et al. 1999; Aldiss \& Edwards 1999). Dykes with more variable orientation at the western end of the WNW-ESE swarm have been separated as the Cape Orford swarm.

The dykes were confirmed as Early Jurassic and linked with the regional Karoo-Ferrar magmatism by Ar-Ar dating (Musset \& Taylor 1994): 190 4 Ma from the Cape Orford swarm and 188 2 Ma from a WNW-ESE dyke (Fig. 1A). Additionally, a NE-SW dyke gave a maximum age of $193 \pm 4$ Ma. A NE-SW dyke gave the crucial palaeomagnetic data cited (Mitchell et al. 1986; Taylor \& Shaw 1989) in support of the rotational tectonic model for the Falklands microplate, which envisages its derivation, during the break-up of Gondwana, from a position adjacent to the SE coast of South Africa (Adie 1952; Marshall 1994; Storey et al. 1999).

This paper presents aeromagnetic evidence for an additional and hitherto unsuspected, N-S Falklands dyke swarm, together with new Ar-Ar ages from East Falkland. These results have substantial implications for the tectonic development of the south Atlantic region.

Aeromagnetic anomalies. An aeromagnetic survey flown during 2004 by Falkland Gold and Minerals Ltd has clearly identified three discrete sets of linear magnetic anomalies interpreted as separate dyke swarms (Fig. 1B. An aeromagnetic anomaly 
map is available online at http://www.geolsoc.org.uk/SUP00000. A hard copy can be obtained from the Society Library). These are:

- a partly radial pattern of dykes (about 80 degrees of arc can be seen) centred to the SW of West Falkland. This includes the WNW-ESE orientated dykes (the "eastwest" swarm sl of earlier literature) and the Cape Orford swarm. Although some of the more prominent dykes within this swarm (with more E-W orientations) appear to cut across the general radial pattern we refer to all of these dykes as the Radial Swarm in this paper. These dykes are all normally magnetised.

- a series of NE-SW trending dykes present in both West and East Falkland (the "north-south" swarm sl of earlier literature). The full extent of these dykes in East Falkland is here demonstrated for the first time. We refer to this swarm as the NESW dykes in this paper. Most of these dykes are reversely magnetised, although some local segments have normal magnetisation.

- a distinctive N-S (swinging northwards to NW-SE) set of approximately 40 dykes, spaced across both East and West Falkland, that produce discrete linear magnetic anomalies unrelated to those from the other swarms. The discovery of this previously unrecognised, N-S dyke swarm has profound implications for the evolution of the Falklands micro-plate and for the extensional histories of the surrounding offshore (possibly petroliferous) sedimentary basins. We refer to this swarm as the N-S dykes in this paper. Most are reversely magnetised in the east, but show both normal and reversed polarities in the west of the archipelago.

A reversed magnetic anomaly provides evidence of a stable reversed remanent magnetisation that is stronger than the magnetisation induced by the Earth's present field. A normal polarity magnetic anomaly does not automatically signify intrusion during a normal geomagnetic polarity interval as it could be due to the dominance of induced over remanent magnetisation. The latter phenomenon might explain instances where the polarity of the magnetic anomaly along a single dyke changes from reversed to normal. On this basis it is not certain that the N-S and NE-SW dyke swarms both span a geomagnetic field reversal, although this appears more likely for the former.

Most of the newly identified N-S magnetic anomalies do not correspond with visible dykes at outcrop, but we have located and sampled dolerite dykes that are unequivocally associated with N-S, linear aeromagnetic anomalies at Teal Creek and in Pony's Pass Quarry (both localities in East Falkland - see Fig. 1B).

New Ar-Ar age dating. Precise Ar-Ar (plagioclase) dates were obtained from the NS dyke at Pony's Pass Quarry and the NE-SW dyke at Port Sussex. The Ar-Ar date obtained at Port Sussex is $178.6 \pm 4.9 \mathrm{Ma}$ (Toarcian), and is based on good plateau results (Fig. 2). Whilst this age is compatible with the previously reported maximum of $193 \pm 4$ Ma (Musset \& Taylor 1994) it establishes the NE-SW swarm as probably younger than the Radial Swarm, which has dates in the range 186-194 Ma. In a regional context, the new Ar-Ar date is closely aligned with the c. 180 Ma peak of Karoo magmatism in South Africa (e.g. Jourdan et al. 2005). A precise Ar-Ar age of 121.3 $\pm 1.2 \mathrm{Ma}$ (early Aptian) was obtained from the Pony's Pass Quarry N-S dyke. The Ar-Ar plateau is well constrained (Fig. 2) and the age is considered to be robust.

Petrology and geochemistry. The compositions of the various Falklands dykes assist our differentiation of three dyke swarms. New data (analytical results are included in 
the supplementary publication) supports published work (Baker 1924; Aldiss \& Edwards 1998; Mitchell et al. 1999) to confirm that:

- the Radial Swarm in the south of West Falkland consists of olivine dolerites with a subordinate clinopyroxene ferromagnesian phase.

- the NE-SW dykes comprise dolerites with two ferromagnesian minerals clinopyroxene and altered orthopyroxene. The composition of the NE-SW dyke at Port Sussex lies at the less-evolved end of the fractionation trend determined by Mitchell et al. (1999) for the NE-SW dykes from West Falkland. The NE-SW dyke from Lively Island (Fig. 1 but outside the aeromagnetic survey area) sits at the more evolved end of this fractionation trend. A broad correlation is therefore likely between the NE-SW dykes from East and West Falkland.

- the newly-identified N-S dykes comprise glassy dolerites with only clinopyroxene in the ferromagnesian phase. The geochemical compositions of the two N-S dykes sampled from East Falkland (Teal Creek and Pony's Pass) are effectively identical to each other, and distinct from those of dykes within the NE-SW and radial swarms. Major oxides exemplify the differences with the N-S Cretaceous dykes being high in $\mathrm{Fe}$ and $\mathrm{Ti}$ but low in $\mathrm{Al}$ and $\mathrm{Mg}$ relative to dykes from the Jurassic swarms (Mitchell et al. 1999, figure 3; cf. supplementary data table). Mitchell et al. (1999) recorded two dykes from West Falkland with 'N-S' chemistry and described them as "evolved examples ... which, if they are related to the rest of the suite at all, have clearly undergone advanced degrees of gabbro fractionation". We suggest that these two dykes are part of the Cretaceous swarm.

Offshore extension of dykes. An offshore extension of the N-S trending dyke swarm has been mapped to the southeast of the Islands (Barker 1999) on the basis of N-S linear magnetic anomalies (Fig. 1B). The continuity of the dyke features indicated by the onshore-offshore datasets is clear, and their reversed polarity is confirmed. The offshore anomalies even show the same northwards swing into a NW-SE alignment that is a feature of the onshore anomalies.

Relationship of the dyke emplacement to offshore basin extension. The Aptian, N$\mathrm{S}$ orientated dykes onshore are of similar age to the oldest oceanic crust recognised from the abyssal plains of the Argentine Basin north of the Falklands-Aghulas Fracture Zone (Fig. 1C). There, marine magnetic anomaly M4 (c. 130 Ma (Gradstein et al. 2004)) has been recorded although somewhat earlier ocean opening is indicated by its distance from the continent-ocean boundary, and by the earlier Mesozoic anomalies (up to M11) on the conjugate margin (Rabinowitz \& LaBreque 1979). It is therefore conceivable that Aptian dyke emplacement on the Falklands was driven by the initiation of sea-floor spreading in the South Atlantic during the early separation of South America and South Africa.

Both the N-S trending and NE-SW trending dykes have striking similarities of trend to the major faults controlling the locations and shapes of offshore basins. The NE-SW early Jurassic dykes lie parallel to the edge of the Falkland Plateau Basin, a major depocentre located east of the Islands (Fig.1C) and with a western margin extending NE-SW for approximately $500 \mathrm{~km}$. The precise age of the earliest stratigraphic fill is unknown, but extensional basin development may have been initiated within the same regional stress field that led to dyke intrusion onshore during the Early Jurassic. The onshore Aptian dykes are parallel to N-S extensional faults recognised throughout the North Falkland Basin (Fig. 1C) and as local features along the western margin of the Falkland Plateau Basin. The North Falkland Basin rifted 
from the late Jurassic onwards, until the early Cretaceous (Richards \& Hillier 2000), and the regional, east-west stress-system responsible was probably also exploited by the onshore dykes.

Regional tectonic considerations. All of the early Permian (Gondwanide) fold and thrust features of the Falkland Islands are cut by dykes, and the aeromagnetic data show no dyke offsets coincident with these major structures. Tectonic activity since dyke intrusion in the Jurassic and Cretaceous has been limited to minor, localised faulting which causes only very small dyke offsets. A possible - but speculative exception might be substantial strike-slip movement along the Falkland Sound Fault, which cannot be resolved from aeromagnetic datasets restricted to the onshore areas.

Following Adie (1952) there is a prevalent view that the Falkland Islands lie on a microplate that was rotated by up to $180^{\circ}$ during its break-out from Gondwana. This model derives largely from onshore geology and is difficult to reconcile with the history of offshore basin expansion in the South Atlantic (Richards et al. 1996). Support for the rotational model was provided by the palaeomagnetic results obtained by Taylor \& Shaw (1989) from a NE-SW, early Jurassic dyke on West Falkland. So, if rotation has occurred, it happened after about $178 \mathrm{Ma}$ but without any significant onshore tectonic effects. Our discovery and dating of the N-S dyke swarm, intruded at about $121 \mathrm{Ma}$ and linked to the rifting of the North Falkland Basin, places an absolute minimum age on the time available for rotation. This minimum age is coincident with that deduced by Taylor \& Shaw based on the age then inferred for the M10 magnetic anomaly, and is compatible with structural evidence from the North Falkland Basin that precludes rotation after the late Jurassic. A definitive test of the rotational model might now be possible through a comparison of the palaeomagnetic characteristics of the Jurassic and Cretaceous dyke swarms, intrusion of which must have respectively preceded and followed any microplate rotation.

There remains one unresolved complication arising from the Aptian date for the N-S dyke swarm - the reversed polarity of many of the constituent dykes contradicts their apparent intrusion during the normal polarity Cretaceous "superchron". The closest established interval of reversed polarity is M0r, which is dated at 124-125 Ma using the timescale of Gradstein et al. (2004). The presence of other dykes within the N-S swarm that have normal polarity admits the possibility that intrusion may have spanned a geomagnetic reversal. Further work is in hand to address this issue and for the present we simply observe that the results reported here (reliable Ar-Ar date linked to clear evidence of magnetic reversal) need to be taken into account in the continuing debate regarding Early Cretaceous chronology.

Conclusions. Recently acquired aeromagnetic results from the Falkland Islands have identified three separate dyke swarms. One is at least partly radial, centred about a point to the west of southern West Falkland and with no representatives on East Falkland. A second swarm comprises dykes trending fairly consistently NE-SW across both West Falkland and East Falkland. Previous dating placed intrusion of all these dykes at about $190 \mathrm{Ma}$. A new Ar-Ar date from one of the NE-SW dykes on East Falkland suggests intrusion at about $178 \mathrm{Ma}$. Most dramatically, the aeromagnetic results show a third and previously undetected suite of dykes trending broadly N-S and spaced across both West and East Falkland. A new Ar-Ar date of about $121 \mathrm{Ma}$ from one of these dykes shows intrusion occurred in the early Cretaceous. By comparison with the offshore area to the north of the islands, it seems likely that these onshore dykes exploited the regional east-west stress regime 
responsible for the rifting of the North Falkland Basin. Hence the time available for any microplate rotation is restricted to the Mid-Jurassic: after intrusion of the early Jurassic, 178 Ma dykes, but before the start of rifting in the late Jurassic.

Falkland Gold and Minerals Ltd are thanked for making available data from their 2004 aeromagnetic survey. Field support was provided by the Department of Mineral Resources, Falkland Islands Government. Derek Ritchie, Phil Leat and Bryan Storey are thanked for reviews of the manuscript. This paper is published by permission of the Falkland Islands Government and the Executive Director, British Geological Survey (NERC).

\section{References}

Adie, R.J. 1952. The position of the Falkland Islands in a reconstruction of Gondwanaland. Geological Magazine, 89, 401-410.

Aldiss, D.T. \& Edwards, E.J. 1999. The Geology of the Falkland Islands. British Geological Survey Technical Report, WC/99/10.

Baker, H.A. 1924. Final Report on Geological Investigations in the Falkland Islands, 1920-1922. Government Printer, Stanley.

Barker, P.F. 1999. Evidence for a volcanic rifted margin and oceanic crustal structure for the Falkland Plateau Basin. Journal of the Geological Society, London, 156, 889900.

Gradstein, J.G., Ogg, A.G. \& Smith, A.G. 2004. A Geologic Time Scale 2004.

Cambridge University Press, Cambridge.

Jourdan, F., Féraud, G., Bertrand, H., Kampunzu, A. B., Tshoso, G., Watkeys, M. K. \& Le Gall, B. 2005. Karoo large igneous province: Brevity, origin and relation to mass extinction questioned by new ${ }^{40} \mathrm{Ar} /{ }^{39} \mathrm{Ar}$ age data. Geology, 33, 745-748.

Marshall, J.E.A. 1994. The Falkland Islands: a key element in Gondwana palaeogeography. Tectonics, 13, 499-514.

Mitchell, C., Taylor, G.K., Cox, K.G. \& Shaw, J. 1986. Are the Falkland Islands a rotated microplate? Nature, 319, 131-134.

Mitchell, C., Ellam, R.M. \& Cox, K.G. 1999. Mesozoic dolerite dykes of the Falkland Islands: petrology, petrogenesis and implications for geochemical provinciality in Gondwanaland low-Ti basaltic rocks. Journal of the Geological Society, London, 156, 901-916.

Müller, R.D., Roest W.R., Royer, J-Y, Gahagan, L.M. \& Sclater, J. G. 1997. Digital isochrons of the world's ocean floor. Journal of Geophysical Research, 102, 32113214. 
Musset, A.E. \& Taylor, G.K. 1994. ${ }^{40} \mathrm{Ar}-{ }^{39} \mathrm{Ar}$ ages for dykes from the Falkland Islands with implications for the break up of southern Gondwanaland. Journal of the Geological Society, London, 151, 79-81.

Rabinowitz, P.D. \& LaBrecque, J.L. 1979. The Mesozoic South Atlantic Ocean and evolution of its continental margins. Journal of Geophysical Research, 84, 59736002.

Richards, P.C., Gatliff, R.W., Quinn, M.F., Williamson, J.P. \& Fannin, N.G.T. 1996. The geological evolution of the Falkland Islands continental shelf. In: Storey, B.C., King, E.C. and Livermore, P. (eds.) Weddell Sea tectonics and Gondwana breakup. Special Publication, Geological Society of London, 108, 105-128.

Richards, P.C. \& Hillier, B.V. 2000. Post-drilling analysis of the North Falkland Basin - Part 1: tectono-stratigraphic framework. Journal of Petroleum Geology, 23, 253-272.

Storey, B.C., Curtis, M.L., Ferris, J.K., Hunter, M.A. \& Livermore, R.A. 1999. Reconstruction and break-out model for the Falkland Islands within Gondwana. Journal of African Earth Sciences, 29, 153-163.

Taylor, G.K. \& Shaw, J. 1989. The Falkland Islands: New palaeomagnetic data and their origin as a displaced terrane from southern Africa. In: Hillhouse, J. W. (ed.) Deep structure and past kinematics of accreted terranes. Geophysical Monographs, 50, 59-72.

\section{Figure captions}

Fig. 1. A) The distribution of dykes mapped in the Falkland Islands prior to the survey described in this paper: WF West Falkland, EF East Falkland, FS Falkland Sound. B) The Falkland Islands showing aeromagnetic lineaments interpreted as dykes and identifying the sampling sites. Colours indicate the polarity of the observed magnetic anomalies (red $=$ normal; blue $=$ reversed). The green line indicates the limit of the aeromagnetic survey. The inset map shows the location of the Falkland Islands and offshore Designated Area (enlarged in Fig. 1C) in relation to South America. C) Age of the oceanic crust adjacent to the Falkland Plateau (after Muller et al, 1997); note that there are discrepancies of up to about $6 \mathrm{Ma}$ between this timescale and that of Gradstein et al (2004) in the Argentine Basin.

Fig. 2. Ar-Ar spectra for the analysed dyke samples (plagioclase separates) from Port Sussex (black) and Pony's Pass Quarry (red). Age errors are shown as $\pm 2 \sigma$.

\section{Supplementary data}

Aeromagnetic image of the Falkland Islands and table of geochemical analyses. 


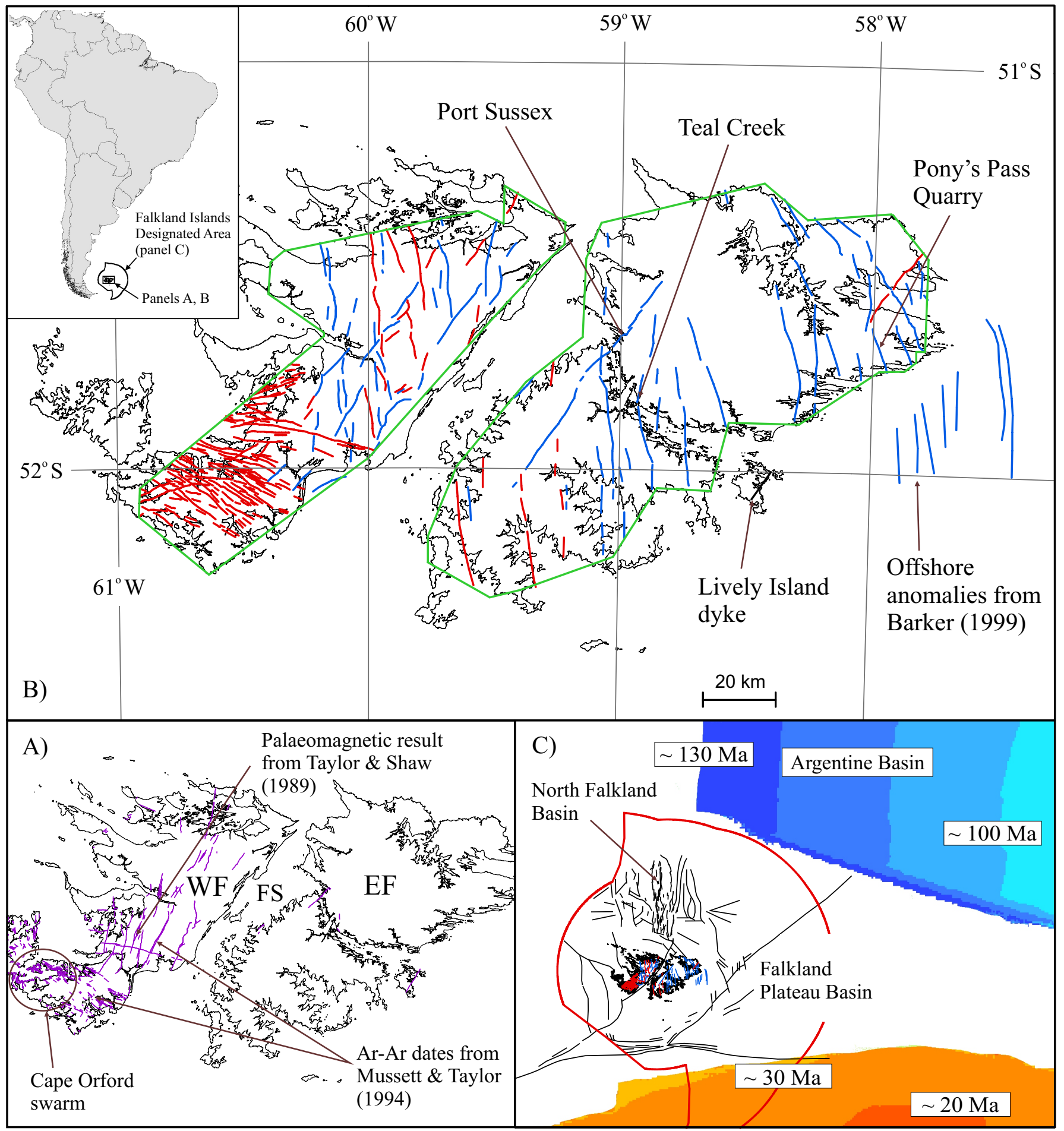


Apparent Age (Ma)

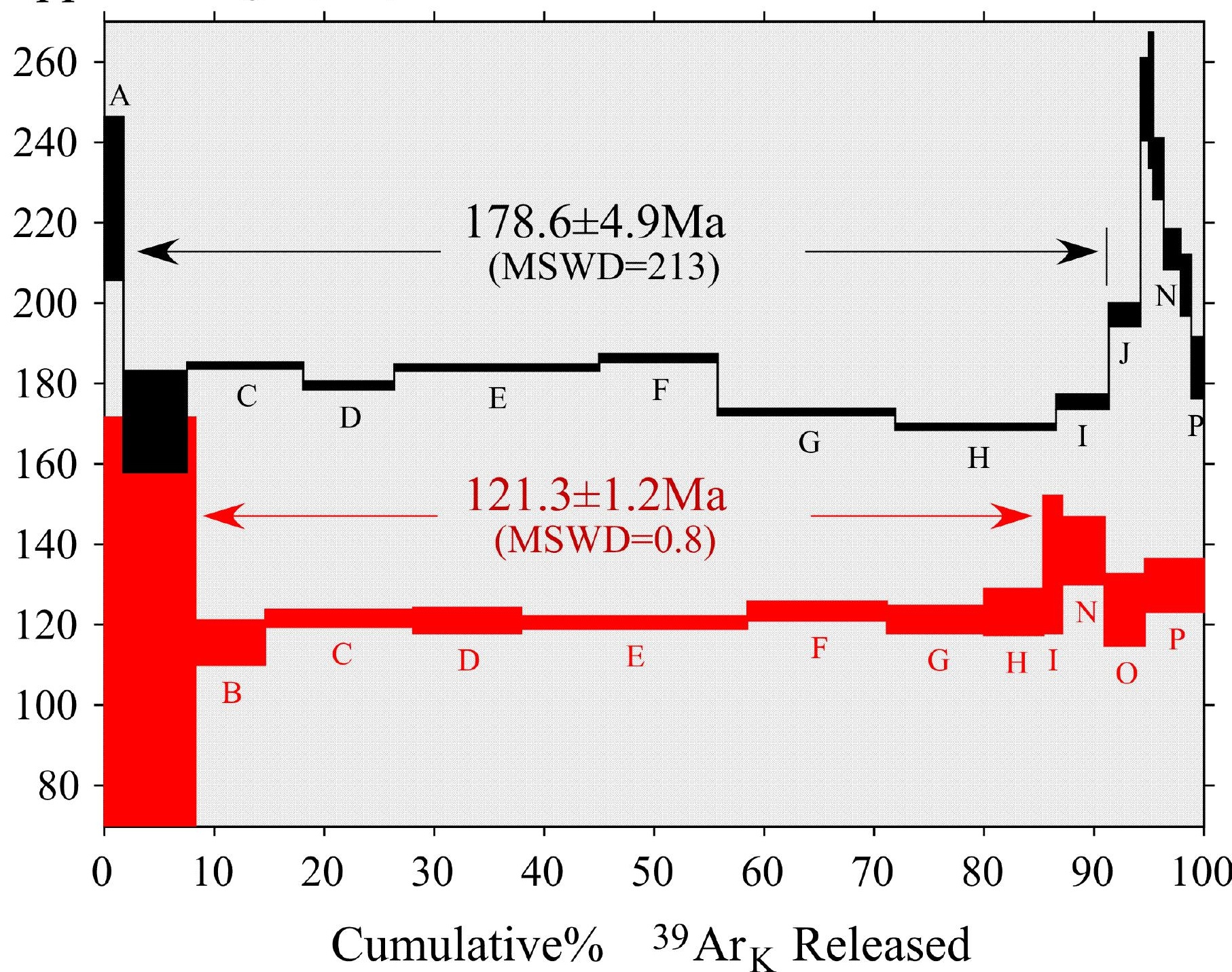

